\title{
Curbing Unemployment Through Job Creation as Panacea to Inclusive Growth in Nigeria
}

\author{
Felicia C. Abada ${ }^{1}$, Benedict I. Uzoechina ${ }^{2}$, Charles O. Manasseh ${ }^{3}$, Ifeoma C. Nwakoby ${ }^{3}$, Paul C. Obidike ${ }^{4}$, Adedoyin \\ I. Lawal ${ }^{5}$, Bukola B. Lawal-Adedoyin ${ }^{5} \&$ Felix C. Alio ${ }^{3}$ \\ ${ }^{1}$ Social Sciences Unit, School of General Studies, University of Nigeria, Nsukka, Nigeria \\ ${ }^{2}$ Department of Economics, Nnamdi Azikiwe University, Awka, Nigeria \\ ${ }^{3}$ Department of Banking \& Finance, University of Nigeria Enugu Campus, Nsukka, Enugu State, Nigeria \\ ${ }^{4}$ Department of Accounting/Banking \& Finance, Alex-Ekwueme Federal University, Ndufu-Alike, Nigeria \\ ${ }^{5}$ Department of Accounting \& Finance, Landmark University, Omu Aran, Nigeria \\ Correspondence: Felix C. Alio, Department of Banking \& Finance, University of Nigeria Enugu Campus, Nsukka, \\ Enugu State, Nigeria.
}

Received: May 29, 2020

doi:10.5430/ijfr.v12n2p376
Accepted: July 17, 2020

Online Published: January 30, 2021

URL: https://doi.org/10.5430/ijfr.v12n2p376

\begin{abstract}
The thrust of this study is to curb unemployment rate through job creation using some key sectors of the economy specifically the manufacturing, agricultural and industrial sectors as the basis for attaining an inclusive growth in Nigeria particularly with the increasing rate of youth unemployment booming the Country. This is demonstrated by the agricultural, manufacturing and industrial policies, programmes and strategies initiated, designed and executed to retard the alarming unemployment rate. The short-run and long-run dynamics streaming from inclusive growth proxied by real gross domestic product per capita, agricultural sector proxied by real agricultural output, manufacturing sector proxied by real manufacturing output, industrial sector proxied by real industrial output and openness measured by export as percentage of real gross domestic product to unemployment rate were evaluated using Autoregressive Distributed Lag (ARDL) bounds test approach for the period 1970 to 2014. The Estimated results from the study reveals that, improvement in the agricultural, manufacturing and industrial sectors will significantly aid in reducing the problems of unemployment and poverty in Nigeria. Even though the manufacturing sector shows no contribution to reducing unemployment, this could be as a result of the use of some equipment which has taken the place of labour thereby making it redundant. Though, if the teeming unemployed populace is adequately trained in the right direction, the manufacturing sector can still absorbed them. To this effect, the study recommended Government to give utmost priority to the key indicators that are needful at a given period of time in order to ascertain the right combination of the sectors in which these scarce resources should be directed to with the intention of enhancing inclusive growth.
\end{abstract}

Keywords: unemployment, inclusive growth, ARDL-bound test, job creation

\section{Introduction}

In most developing countries and particularly Nigeria, unemployment is becoming an increasingly alarming and worrisome socio-economic malaise looming the fortunes of the country since youths are the worst stroke. The unemployment rate in Nigeria is quite deleterious growing consistently every year at the rate of $23.8 \%$ (World Development Indicator, WDI, 2015). Unemployment has become a major problem bedeviling the lives of Nigerian youths causing frustration, dejection and dependency on family members and friends, who also have their own lots of problems to grapple with. The piercing rate of unemployment among the youths in Nigeria has contributed to the high rate of heinous practices such as militancy, Boko Haram insurgence, drugs trafficking, kidnapping, armed robbery, prostitution, smuggling and insecurity of all kinds. Thus, Productive and decent job creation is a vital means of income and security.

However, curbing unemployment becomes crucial to achieving an inclusive growth in Nigeria by creating largely mutual chance to everyone employable in the agricultural, manufacturing and industrial sectors of the economy. According to WDI (2015), unemployment is awfully high in Nigeria among the youths reaching $14 \%$ in spite the considerable increase in economic growth. However, in order to create self-dependency and gainful employment that 
can leads to inclusive growth in Nigeria, certain governmental programmes and policies were inaugurated such as the introduction of vocational courses in the educational curriculum in 1997, the creation of the National Directorate of Employment in 1986 solely for skills acquisition; industrialization programmes and policies; the National Economic Empowerment and Development Strategy designed in 2004 with one of its goal tuned towards fighting unemployment and the Agricultural programmes and policies geared at generating employment for graduates, non-graduates and school leavers in the Agricultural sector coupled with election promises (Nkwatoh, 2012; Udo, 2014). Despite these measures, unemployment rate has not declined rather it continue to rise.

Few studies have been done on unemployment and economic growth in Nigeria amidst others is (Onwachukwu, 2015; Salami, 2013; Adawo, Essien \& Ekpo, 2012; Umaru, Donga \& Salihu, 2013; and Njoku \& Ihugba, 2011). However, most of these studies concentrated on explaining the relationship between unemployment and economic growth or pro-poor growth with little or no attention tilted towards inclusive growth. Therefore, this study intends to focus on some key sectors in the economy such as manufacturing, industrial and agricultural sectors and how these sectors can aid in narrowing the gap created by unemployment which might have obstructed inclusive growth. Nonetheless, Inclusive growth cannot be attained with a majority of the population who are able and willing to work not having anything to do at all to fetch them their daily means of living. Thus, this research will also appraise efforts of the past governments in purposive job creation geared towards curtailing unemployment in Nigeria over the period 1970 to 2014.

\section{Literature Review}

\subsection{Conceptual Issues}

Unemployment is an important determinant of the level of economic growth and development in which every country strives to remedy. According to Bello (2003), unemployment from time immemorial has been a subject of great concern to the economists, policy makers and managers alike leaving the devastating effect of this phenomenon on individuals, the society and the economy at large. Adebayo (1999) defined unemployment as a state in which people who can work are without jobs and are seeking for pay or profit. Unemployment occurs when people are without jobs and they have actively sought for job within the past four weeks (International Labour Organization, ILO, 2009). Thus, unemployment refers to a situation where people who are willing and capable of working could not find suitable paid employment. By implication, this definition described unemployment as a situation in which people who are willing to work at the prevailing wage rate are unable to find jobs.

On the other hand, Inclusive growth is one of the most conceptualized term in recent time, even though, there seems not to be a common definition, this concept however is largely understood to be growth coupled with equal opportunities. Existing studies revealed that Gross Domestic Product (GDP) and GDP per capita are inadequate in estimating the wellbeing of its citizens. According to Kraay (2004) and Berg and Ostry (2011), growth is inclusive if it is sustainable and efficient in reducing poverty and income inequality. In line with Ianchovichina and Lundstrom (2008), inclusive growth involves a long-term perspective and focuses on generating decent employment in order to increase the income of excluded groups. Ali and Zhuang (2007) described inclusive growth as growth allowing every individual of the society to actively participate in and contribute to the growth process on an equal footing regardless of their individual circumstances. In keeping with Rauniyar and Kanbur (2009), inclusive growth is one which emphasizes available economic opportunities to all as created by growth, mostly to the poor. Hence, growth is inclusive if the benefits will reach the poor, marginalized and socially excluded groups in the society. This kind of growth should bring about social development and empowers the weaker groups in the society to gain access to assets and opportunities, while equitable distribution of assets and opportunities brings about sustainable economic growth and by extension results in reduction of poverty and income inequality.

\subsection{Review of Related Empirical Literature}

From the empirical front, the relationship between unemployment and Economic growth over the period 1985 to 2009 in Nigeria was conducted by Njoku and Ihugba, (2011). The study confirms that the workforce directly impacts on a country's GDP. Thus, the economy grew by $55.5 \%$ between 1991 and 2006 as the population rose by $36.4 \%$. The study revealed further that the average contribution of the oil sector to the GDP between 1991 and 2006 was $30.5 \%$ while agriculture that is the main source of job creation in the country contributed $36.7 \%$, a difference of 6.1 percent from that of oil that employs less than $10 \%$ of the labour force. Onwachukwu, (2015) investigated if unemployment significantly impacted on Economic growth in Nigeria over the period 1985 and 2010. Estimation results from OLS and Augmented Dickey Fuller (ADF) confirmed that, unemployment negatively influenced economic growth though not statistically significant probably as a result of ghost workers that might have been counted among the employed citizens that are not contributing to output. 
The ties between entrepreneurial development and unemployment with its implication for economic growth in Nigeria were investigated by Nkwatoh, (2015) in Nigeria within 1982 and 2013. The study used Ordinary least square (OLS) with particular interest in heteroskedasticity in which its estimation results created the occurrence of a twin effect. Entrepreneurial development therefore curbed future unemployment and also unemployment engenders entrepreneurship development. Thus, education can be identified as a stimulant for the negative relationship between unemployment and inclusive growth. The relationship between unemployment and economic growth was argued by Acemoglu (1997) as resulting from the links between unemployment levels, employer expectations and worker productivity. When high unemployment is experienced through loose labour market, firms anticipate that the likelihood of finding an unskilled worker is strong. This implies less willingness to hire because such conditions call for workers to be trained in order to develop target qualifications. As a consequence, growth dynamics are lower and an unemployment rate increases, which means that an agent's expectations are inadequately met. In explaining unemployment and its solution in Nigeria, Mike (2015) used descriptive analysis to offer solutions to curbing unemployment in Nigeria such as improving agricultural sector of the economy, improving our mindset, promoting quality education among others.

Similarly, Oji-Okoro, (2011) confirmed the agricultural sector as the largest sector in the Nigerian economy with its dominant share of the GDP that can absorb over $70 \%$ of the active labour force and the generation of about $88 \%$ of non-oil foreign exchange earnings. Its share of the GDP frog-leaped from an annual average of 38\% during 1992 to 40\% in 1996 during 1977-2001 compared to crude oil the GDP from which it nose-dived from an annual average of $13 \%$ to $12 \%$ in 1992 and 1996. The major role agriculture plays in developing countries particularly Nigeria for overall economic development was recognized by Ogbalubi and Wokochha (2013) in their study on Agricultural Development and employment generation. The study describes the agricultural sector as the most critical and basic sector that has significant potentials for the revolution of the Nigerian economy. The findings of the research indicated that, the potentials of the sector are yet to be fully optimized. Analogously, Olajide, Akinlabi \& Tijani (2012) analyzed the relationship between Agricultural resource and economic growth in Nigeria using OLS over the period 1970 to 2010. The estimation results revealed a positive cause and effect relationship between gross domestic product (GDP) and agricultural output in Nigeria. Agricultural sector was found to have contributed $34.4 \%$ to economic growth though it suffered neglect during the prime days of the oil boom in the 1970s.

\subsection{Attempts at Curbing Unemployment in Nigeria}

Nigerian government over time have made the acquisition of requisite skills pivotal as part of its initiative in promoting self-reliance and contentment in creating meaningful employment opportunities. It commenced with acquiring of vocational skills due to credence given to the educational system that functioned since post-independence placing more emphasis on academic excellence rather than skill acquisition which can put the individuals in order for more useful and rewarding life adventures within the society. This made development of a country essential and dependent particularly on Vocational skills acquisition. Thus, Emeh (2012) argued that, vocational courses in educational curriculum emerged as a result of the new national policy on education decree of 1977.

According to Omoruyi and Osunde (2004), the intrinsic goal of setting Chukwuma Committee on March 26, 1986 was to reverberate the ineffectiveness of the vocational courses in the school curriculum purposely to address unemployment especially among youths by the federal government which has assumed a frightening magnitude. The report of the Chukwuma led Committee resulted to the creation of the National Directorate of Employment (NDE) in November 22, 1986 saddled with the sole task of advancing skills acquisition; expedite creative attitude, self-sufficiency and independence. To be frank, vocational skills training is under due consideration previously because many centres have been set up. The most widely spread interest of NDE is swift and successful control of unemployment by designing and putting into use groundbreaking programmes geared towards the provision of training opportunities across the leadership and administrative support services to graduate, non -graduate farmers and small scale entrepreneurs. Furthermore, National Economic Empowerment and Development Strategies (NEEDS) was drawn in 2004 mainly to fighting unemployment coupled with election promises which maintained that many of the responses to poverty reduction appeared to be temporal, awkward and more or less haphazard (NEEDS, 2004; Nkwatoh, 2012).

These Programmes involves among others Community Bank, Directorate of Food Roads and Rural Infrastructure (DFRRI), National Directorate of Employment (NDE), People's Bank, Better Life for Rural Women/Family Support Programme, the Development of Small and Medium Scale Enterprises (SMSE) and the Raw Materials Research and Development Council (RMRDC). The current poverty alleviation programme also focuses on the unemployed in 
which some of these projects aimed at addressing various manifestations of poverty. This led to the establishment of several government parastatal whose primary objective was to generate employment opportunities in addition to the creation of institutions such as the Industrial Training Fund (ITF), YOU-Win amidst others which have considerably reduced the problem of unemployment in Nigeria.

The agricultural sector is not left behind in this stride. In Nigeria, the Agricultural sector has contributed immensely to reducing unemployment by initiating some programmes and policies capable of generating employment for graduates, non-graduates and school leavers in the Agricultural sector. The Agricultural sector within the last two decades operated under a number of policy measures and programmes designed to strengthen the economic position of the independent farmers. These programmes and policies as corroborated by Anyanwu, (1997) includes the National Accelerated Food Production Project (NAFPP) established in 1973, the Nigerian Agricultural and Co-operative Bank (NACB) founded in 1973, the Nigerian Agricultural and Co-operative Bank (NACB) founded in 1973, the River Basin Development Authorities (RBDAs) of 1963, Operation Feed the Nation (OFN) launched in 1976; the Agricultural Credit Guarantee Scheme (ACGS) created by an act in 1977; the National Agricultural Land Development Authority (NALDA) formed in 1991. The sole aim of these programmes and policies were to boost agricultural production and self-sufficiency; Creation of more agricultural and rural employment opportunities to increase the income of farmers as well as rural dwellers and to productively absorb an increasing labour force in the nations; to improve the quantity and quality of credit to all aspect of agricultural production; to easy mobilization of savings that would be invested in the agricultural sector and to moderate the chronic problem of low utilization of abundant farm land.

The industrial sector on the other hand have strived to curb unemployment through Import Substitution Industrialization Strategy (ISI) adopted in 1960 and existed till 1985.The ISI aimed at intensifying domestic production of manufactured goods for domestic markets by encouraging the survival of home industries through imposing restrictive tariffs such as import quotas and exchange controls to protect the home industries from unhealthy competition making the entry of foreign firms expensive (Bushari, 2005).Export Promotion Strategy(EPS) was another policy tool used in generating more foreign exchange from non-oil sources to meet the country's rising import bills, mounting external debt obligations, rising fiscal responsibilities of the government and to attend to socio-economic responsibilities. As a result, having more access to foreign market as contended by Obioma and Ozughalu, (2005) can be provided by reducing unemployment through increase in private sector participation in the industrial sector. Finally, Foreign Private- Investment Led Industrialization Strategy (FPLIS)emerged in 1999 to repose confidence to business associates due to the past military experience of Nigeria. Thus, marking the beginning of foreign private-investment led industrialization into Nigeria's industrial policy. This new policy involves in building new facilities, merging and acquisitions, reinvesting profits earned from overseas operating and intra company loan (Udo, 2014).

Inclusive growth can be attained through the manufacturing sector. However, in Nigeria, this sector is still in its infancy stage. To raise manufacturing output, suitable policies should be made and implemented to support the industries where Nigeria has comparative advantage. Accordingly, the Nigeria Industrial Revolution Plan (NIRP) has pioneered the creation of policies for automotive and sugar sectors. NIRP seeks to improve access to these sectors and improve the business environment to encourage investment in local manufacturing. Also, there is the need to attract foreign direct investments (FDI) in non-oil sector that would provide maximum employment opportunities, (McKinley, 2010).

\section{Methodology}

\subsection{Theoretical Framework}

This study used the Okun's law which establishes the relationship between economic growth and the rate of change in unemployment. Okun (1962) treats unemployment in declining rate as against the actual or potential growth rate attained by an economy. Thus, in order to reduce unemployment rate, Okun assumed the economy's growth rate to exceed the natural growth boundary. The association between unemployment $(\mathrm{U})$ and growth rate $\left(\mathrm{Y}^{*}\right)$ according to Okun's law is demonstrated as shown below:

$$
U=a+b\left(Y-Y^{*}\right)
$$

In determining the actual rate of growth $\left(\mathrm{Y}^{*}\right)$ and how it changes over time, a dynamic analysis of Okun's law can be reestablished as:

$$
\mathrm{Y}+\Delta U=a+b \Delta \varepsilon
$$

Where: 
$\Delta U=$ is the change in the unemployment rate,

$\mathrm{Y}=$ as economic growth rate,

$\mathrm{Y}^{*}=$ Actual growth rate

$\mathrm{B}=$ denotes flexibility between growth and unemployment rate and

$\varepsilon=$ is the error term.

From equation (2), a and b described the extent to which the percentage change in natural growth rate reflects rate of unemployment when there is a fall. On the other hand, if the rate of unemployment could not change $(\Delta U=0)$ the growth rate will keep on expanding at the actual or natural rate as shown in equation 3.3 below:

$$
\mathrm{Y}^{*}=-\alpha / b
$$

The stability of unemployment rate is ensured if the growth rate foreseen to keep the unemployment rate is fixed or constant. Thus, the influence of growth rate on unemployment rate is initiated when growth rate exceeded the actual or natural rate. The nexus is done between the rising rate of growth and the declining rate of unemployment to show that, in an event of growth rate, there is no change in unemployment rate. This can be depicted below as:

$$
b=\Delta U / \Delta \mathrm{Y}
$$

From equation (4) above, $\mathrm{b}$ described the relationship involving unemployment and the growth rate determined by the magnitude of change induced at every change in the constant economic growth.

\subsection{Data Sources and Variable Definitions}

This study will utilize annual dataset obtained for the period 1970 to 2014 having 45 observations. The period is chosen due to the availability of relevant data required for the study and its adequacy to capture both the short- and long-run dynamics of job creating avenues. The dataset was drawn from Central Bank of Nigeria (CBN) 2015 Statistical Bulletin, Annual Report and Statements of Account, the National Bureau of Statistics (NBS) and the World Bank Development Indicators (WDI, 2015) online database. The variables used in the study include Unemployment Rate (UEMR), inclusive growth to be proxied by real Gross domestic product per capita (GPC), Agriculture sector to be proxied by real agricultural output (AGRIC), manufacturing sector to be measured by real manufacturing output (MANUF), Industrial sector to be measured by real industrial output (INDUS), and openness measured by export as percentage of real GDP (OPNX).

\subsection{Estimation Technique}

The study employed the Autoregressive Distributed Lag (ARDL) bound test approach to determine the short- and long-run dynamics between unemployment rate and measures through which job can be created (Agricultural, manufacturing, industrial) in order to enhance inclusive growth in Nigeria. Unlike other conventional co-integration tests such as Engle and Granger (1987) and Johansen and Juselius (1990), the ARDL bound test approach can be applied to variables of different order of co- integration being I (0) or I (1) process (Pesaran \& Shin,1997). Second, the ARDL approach is applicable to small or finite sample size and therefore conducting bound test will be appropriate to this study (Pesaran, Shin \& Smith, 2001; Narayan, 2011). Third, the short and long-run parameters of the model are estimated simultaneously removing problems associated with omitted variables and autocorrelation (Huag, 2002); the ARDL technique generally provides unbiased estimates of the long-run model and valid $t$-statistics even when some of the regressors are endogenous. Finally, this approach has the flexibility that can accommodate structural breaks in time series data. To this effect, the study will utilize the ARDL bound approach to examine the extent at which the agricultural and the industrial as well as the manufacturing sectors expedite the curb of unemployment by creating jobs for inclusive growth to be enhanced in Nigeria.

In this empirical analysis, the statistical properties of the data are examined via the Augmented Dickey Fully (ADF) and the Phillips-Perron (PP) test to ward off any tendency of having a spurious result after determining its maximum lag length via Akaike Information Criterion (AIC). If unit root is confirmed in more than one variable including the dependent variable, the ARDL bound test will be conducted to affirm if exist long run relationship among the variables. Following the model specifications, the statistical properties of the data can be verified with the unrestricted error correction model (UECM) of the bound used in restoring equilibrium in the long run.

\subsection{Model Specifications}

To specify this model, the sectors and other policy variables through which jobs can be created to curb unemployment in Nigeria are substituted in equation (1) to have 


$$
U E M R_{t}=f\left(G P C_{t}, A G R I C_{t}, M A N U F_{t}, I N D U S_{t}, O P N X_{t}\right)
$$

The functional relationship of the model specified above can be expressed in an estimable form as shown in equation (6) below:

$$
U E M R_{t}=\beta_{0}+\beta_{1} G P C_{t}+\beta_{2} A G R I C_{t}+\beta_{3} M A N U F_{t}+\beta_{4} I N D U S_{t}+\beta_{5} O P N X_{t}
$$

Where UEMR; Unemployment rate, GPC; Inclusive growth to be measured via real Gross Domestic product per capita, AGRIC; Agricultural sector to be proxied by real agricultural output, MANUF; Manufacturing sector to be proxied by real manufacturing output, INDUS; Industrial Sector to be measured by real industrial output and OPNX; Openness proxied by export as percentage of real GDP. According to a priori expectations, real agricultural output, real manufacturing output, real industrial output, real gross domestic product per capita as proxy of inclusive growth, openness proxied by export as measure of real GDP exhibits a negative relationship with unemployment rate $\left(\beta_{1}, \beta_{2}, \beta_{3}, \beta_{4}, \beta_{5}<0\right)$. The higher the real output obtainable from these sectors, the lesser the number of unemployment rate. Also, when the degree of trade openness in a country is enormous, the rate of economic growth will increase since trade openness facilitates greater integration into the global economy and promotes growth through the channels of better resource allocation, greater competition, innovation, transfer of technology and access to foreign savings which invariably reduce the soaring unemployment rate in the Country by creating job openings. However, in order to incorporate both the short run and long run dynamics of unemployment rate and sectors via which it can be harnessed with the intention of creating job opportunities are expressed using ARDL bound test procedure as demonstrated below:

$$
\begin{aligned}
\text { UEMR }_{t} & =\alpha+\phi_{1} \text { UEMR }_{t-1}+\phi_{2} \text { LnGPC }_{t-1}+\phi_{3} \text { LnAGRIC }_{t-1}+\phi_{4} \text { LnMANUF }_{t-1}+\phi_{5} \text { LnINDUS }_{t-1} \\
& +\phi_{6} \text { LnOPNX }_{t-1}+\sum_{m=1}^{q} \theta_{m} \Delta \text { UEMR }_{t-m}+\sum_{n=1}^{q} \varpi_{n} \Delta \operatorname{LnGPC}_{t-n}+\sum_{r=1}^{q} \psi_{r} \text { LnAGRIC }_{t-r}+\sum_{x=1}^{q} \omega_{x} \Delta \text { LnMANUF }_{t-x} \\
& +\sum_{z=1}^{q} \beta_{z} \Delta \text { LnINDUS }_{t-z}+\sum_{h=1}^{q} \varphi_{h} \Delta \text { LnOPNX }_{t-h}+\ell_{t}
\end{aligned}
$$

Where $\alpha$ describes the intercept, Ln denotes the natural log operator, $\phi=1-6$ are the long run multipliers of the

model, $\theta_{m}, \varpi_{n}, \psi_{r}, \omega_{x}, \beta_{z}, \varphi_{h}$ denotes the short-run dynamic coefficients of the parameters While $\Delta$ is the first difference operator and $q$ is the optimal lag length to be decided by Akaike Information Criterion (AIC) and $\ell_{t}$ as the disturbance term. The next step is to estimate the ARDL bounds testing on equation 3.7 to establish if long run relationship exist among the variables by conducting the F-test (Wald test) for the joint significance of the coefficients of the lagged levels of the variables: $H 0: \phi_{1}=\phi_{2}=\phi_{3}=\phi_{4}=\phi_{5}=\phi_{6}=0$ as against the alternative hypothesis $H 1: \phi_{1} \neq \phi_{2} \neq \phi_{3} \neq \phi_{4} \neq \phi_{5} \neq \phi_{6} \neq 0$

However, the computed F-statistic will be compare with the critical value developed by Pesaran et al (2001) and modified by Narayan (2011) to suit small sample size ranging from 31 to 80 observations which is found relevant in this study with 45 number of observations. The presumed critical values are $\mathrm{I}(0)$ for lower bounds and $\mathrm{I}(1)$ for upper bounds. If the F-calculated exceeds the upper bounds, then the null hypothesis (H0) should be rejected while it should not be rejected if the F-calculated value falls below the lower bounds. Consequently, if the F-calculated statistic lies in between the upper and the lower bounds value, it is an indication that the result is indecisive (Pesaran 
et al, 2001; Narayan, 2011). If a long-run and stable relationship is endorsed by equation 3.7, then the conditional ARDL (v, n, c, t, k, r) model will be set up using:

$$
\begin{aligned}
\text { UEMR }_{t} & =\beta+\sum_{j=0}^{v} \pi_{1} \text { UEMR }_{t-j}+\sum_{j=0}^{n} \pi_{2} \text { LnGPC }_{t-j}+\sum_{j=0}^{c} \pi_{3} \text { LnAGRIC }_{t-j}+\sum_{j=0}^{t} \pi_{4} \text { LnMANUF }_{t-j} \\
& +\sum_{j=0}^{k} \pi_{5} \text { LnINDUS }_{t-j}+\sum_{j=0}^{r} \pi_{6} \text { LnOPNX }_{t-j}+\mu_{t}
\end{aligned}
$$

All the variables retained their previous explanation and $\mathrm{v}, \mathrm{n}, \mathrm{c}, \mathrm{t}, \mathrm{k}$ and $\mathrm{r}$ are the optimal lag length to be decided by AIC while $\pi=1-6$ are the long run parameters. Once estimation of the related long-run multipliers are fulfilled, the short-run dynamic coefficients is investigated using error correction model (ECM) of ARDL (v, n, c, t, k, r) as expressed in equation 3.9 below:

$$
\begin{aligned}
\Delta \text { UEMR }_{t} & =\varphi_{0}+\sum_{i=0}^{V} \Omega_{1 i} \Delta \text { UEMR }_{t-i}+\sum_{i=0}^{n} \Omega_{2 i} \Delta L n G P C_{t-i}+\sum_{i=0}^{c} \Omega_{3 i} \Delta \text { LnAGRIC }_{t-i}+\sum_{i=0}^{t} \Omega_{4 i} \Delta M A N U F_{t-i} \\
& +\sum_{i=0}^{k} \Omega_{5 i} \Delta I N D U S_{t-i}+\sum_{t=0}^{T} \Omega_{6 i} \Delta O P N X_{t-i}+\delta E C M_{t-1}+\varepsilon_{t}
\end{aligned}
$$

From equation (9), $E C M_{t-1}$ denotes the Error Correction Model (ECM) towards long-run equilibrium after short-run shock and while $\delta$ explains the speed by which the parameters converges back to equilibrium. The coefficient of the error term must be negative and significant to ensure convergence of the long-run dynamics towards equilibrium. The value of $\delta$ fluctuates between -1 and 0 . When the coefficient is -1 , there is a sudden and complete convergence while 0 implies no meeting after experiencing the shock. The goodness of fit of the model can be checked through post-diagnostic test like serial correlation, heteroscedasticity test, functional form, normality test and stability test such as Cumulative sum of Recursive Residuals (CUSUM) and Cumulative Sum of squares of Recursive Residuals (CUSUMSQ).

\section{Analysis of Empirical Results}

\subsection{Descriptive Statistic}

The study employed the use of time series variables specified using unemployment rate (UEMR), real per capita output to proxy inclusive growth (LnGPC), manufacturing sector proxied by real manufacturing output (LnMANUF), industrial sector to be measured by real industrial output (LnINDUS), agricultural sector proxied by real agricultural output (LnAGRIC) and Trade openness as measure of the percentage of GDP (OPNX). However, the mean, median, standard deviation, minimum, maximum, skewness as well as the Jarque-Bera statistics of each variable used in this model and their relevant characteristics are as described in Table 1 below. The validity of the variables in this research are supported by the mean, Median, skewness and as well as the minimum and maximum magnitude of the variables. The variables are normally distributed as indicated by Jarque-Bera statistic as demonstrated below.

Table 1. Results of descriptive statistic

\begin{tabular}{lcccccr}
\hline & UNEMP & OPNX & LnMANUF & LnINDUS & LnGPC & LnAGRIC \\
\hline Mean & 8.071111 & 0.295796 & 9.410690 & 11.14460 & 7.125313 & 11.18639 \\
\hline Median & 6.100000 & 0.277599 & 9.543867 & 11.59139 & 7.334191 & 11.40027 \\
\hline Maximum & 18.10000 & 0.497284 & 15.71526 & 16.43954 & 12.84545 & 16.54860 \\
\hline Minimum & 1.900000 & 0.129009 & 5.729125 & 6.708206 & 3.170323 & 7.500364 \\
\hline Std. Dev. & 4.823693 & 0.105088 & 2.104696 & 2.090400 & 2.121113 & 2.123481 \\
\hline Skewness & 0.609076 & 0.212300 & 1.169042 & 0.221822 & 0.638107 & 0.422020 \\
\hline Kurtosis & 1.812715 & 1.900377 & 5.958517 & 4.434478 & 4.717348 & 3.901230 \\
\hline
\end{tabular}




\begin{tabular}{lllllll}
\hline Jarque-Bera & 5.425393 & 2.605228 & 26.66150 & 4.227276 & 8.583761 & 2.858658 \\
\hline Probability & 0.066358 & 0.271820 & 0.000002 & 0.120798 & 0.013679 & 0.239470 \\
\hline Sum & 363.2000 & 13.31083 & 423.4811 & 501.5072 & 320.6391 & 503.3877 \\
\hline Sum Sq. Dev. & 1023.792 & 0.485912 & 194.9088 & 192.2699 & 197.9613 & 198.4035 \\
\hline
\end{tabular}

Source: Author's Computation

Accordingly, the value of the mean and median of the variables as observed from the table are not too far from each other except that of unemployment (UEMR). This is an indication of no extreme outliers and hence, making the variables normal for analysis. The value of standard deviation of each variable is a cursory advancing towards normal distribution. Moreover, the skewness, Kurtosis and Standard deviation statistics denotes that the differences in the variables are not too significant. This analysis indicates that variables capable of curbing unemployment in order to enhance inclusive growth in Nigeria over the period 1970 to 2014 can be significant after being normalized.

\subsection{Unit Root Test}

From Table 2 below, the unit root tests using the ADF and PP techniques are recounted. The essence of employing $\mathrm{ADF}$ and PP is to examine the null hypothesis of non-stationarity which is rejected if the ADF and PP is more negative or greater than the critical values in absolute sense at $1 \%, 5 \%$ and $10 \%$ level of significance. Thus, both the $\mathrm{ADF}$ and the PP results indicated that all the variables are non-stationary at levels. However, all the series became stationary after taking their first differences except trade openness as percentage of real GDP which is stationary at level.

Table 2. Results of unit root test

\begin{tabular}{|c|c|c|c|c|c|c|}
\hline & \multicolumn{2}{|c|}{$\begin{array}{l}\text { Augmented Dickey Fuller (ADF) } \\
\text { test }\end{array}$} & \multirow[t]{2}{*}{$\begin{array}{l}\text { Order of } \\
\text { Integration }\end{array}$} & \multicolumn{2}{|c|}{ Phillips-Perron } & \multirow[t]{2}{*}{$\begin{array}{l}\text { Order of } \\
\text { Integration. }\end{array}$} \\
\hline & t-stat & Critical Val & & t-stat & Critical Val & \\
\hline UEMR & -5.8887 & $-3.5966 * * *$ & $\mathrm{I}(1)$ & -7.1959 & $-4.1865 * * *$ & $\mathrm{I}(1)$ \\
\hline LnAGRIC & -6.6981 & $-3.5924 * * *$ & $\mathrm{I}(1)$ & -6.7543 & $-3.5925 * * *$ & $\mathrm{I}(1)$ \\
\hline LnMANU & -6.3852 & $-3.5925 * * *$ & $\mathrm{I}(1)$ & -6.3852 & $-3.5925 * * *$ & $\mathrm{I}(1)$ \\
\hline $\mathrm{F}$ & -6.7706 & $-3.5925 * * *$ & $\mathrm{I}(1)$ & -6.7084 & $-4.1865 * * *$ & $\mathrm{I}(1)$ \\
\hline LnINDUS & -6.6250 & $-3.5924 * * *$ & $\mathrm{I}(1)$ & -6.6242 & $-4.1865 * * *$ & $\mathrm{I}(1)$ \\
\hline LnGPC & -2.8057 & $-2.6030^{*}$ & $\mathrm{I}(0)$ & -2.6537 & $-2.6031^{*}$ & $\mathrm{I}(0)$ \\
\hline
\end{tabular}

Note: $* * *, * *$ and $*$ denotes level of significance at $1 \%, 5 \%$ and $10 \%$, respectively. Also, unemployment rate and export as a percentage of GDP are not log form because the variables are in percentage.

The unit root results fulfilled the underlying assumptions that necessitate the use of ARDL-bound test to affirm if long-run associations exist among the variables in Nigeria as extracted from Narayan $(2004,2011)$ procedure. The results of the ARDL bounds testing are as demonstrated below in Table 3.

\subsection{ARDL-Bound Test of Cointegration}

\begin{tabular}{llllll}
\hline t-Statistic & Value & K & Level of Sig & \multicolumn{2}{l}{ Bound critical Values } \\
\cline { 3 - 6 } & & & & $\mathbf{I}(\mathbf{0})$ & $\mathbf{I}(\mathbf{1})$ \\
\hline \multirow{2}{*}{ F-Statistic } & 4.257280 & 5 & $1 \%$ & 3.93 & 5.23 \\
\cline { 2 - 6 } & 4.257280 & 5 & $5 \%$ & 3.12 & 4.25 \\
\cline { 2 - 6 } & 4.257280 & 5 & $10 \%$ & 2.75 & 3.79 \\
\hline
\end{tabular}

Source: Author's computation 
Given that unemployment rate is integrated of order one or is an I(1) process, it is crystal clear that there is a cointegrating relationship streaming from agricultural output, manufacturing output, industrial output, export output measured as percentage of GDP and real per capita output to Unemployment rate. However, the calculated F-test statistic (4.26) from Table 3 above is greater than the upper critical bound values of Narayan at $5 \%$ and $10 \%$ level of significance i.e $(4.26>|4.25||3.79|)$. This bound result affirmed that, the null hypothesis of no cointegration cannot be accepted for Nigeria over the period 1970 to 2014. Since the variables are cointegrated, the long run model will be estimated using ARDL of the sample period as described below.

\subsection{Estimated Long-Run Coefficients of the Relationship}

Having confirmed the existence of cointegration among the variables involved, it become appropriate to evaluate the long-run elasticities among the variables using equation 3.8 following ARDL ( $\mathrm{v}, \mathrm{n}, \mathrm{c}, \mathrm{t}, \mathrm{k}, \mathrm{r}$ ) specification as thus:

Table 3. Coefficients of long run parameters

\begin{tabular}{llll}
\hline Variable & Coefficient & t-Statistic & Probability \\
\hline C & 45.21862 & 2.042919 & 0.0479 \\
\hline LNGPC & -13.84395 & -2.266435 & 0.0290 \\
\hline LNAGRIC & -0.264209 & -6.288294 & 0.0000 \\
\hline LNMANUF & 4.183946 & 1.586098 & 0.1208 \\
\hline OPNX & 1.418627 & 0.243752 & 0.8087 \\
\hline LNINDUS & -8.954231 & -4.473595 & 0.0001 \\
\hline
\end{tabular}

Source: Author's Computation; ARDL (v, n, c, t, k, r) decided by AIC with UEMR as the dependent variable

The long run coefficients from Table 3 can be expressed in equation form as demonstrated below:

$$
\begin{array}{r}
\text { UEMRt }=45.21862-13.84395 * \text { LNGDP-0.264209*LNAGRIC+4.183946*LNMANUF+1.418627*OPNX-8.954231*L } \\
\text { NINDUS }
\end{array}
$$

The estimated results of the long-run relationship suggests the agricultural, manufacturing and industrial sectors as the key driving forces of curbing unemployment via job creation forming the basis of adjudging inclusive growth in Nigeria. From Table 3 above, inclusive growth proxied by real output per capita exhibits a statistically significant negative relationship with the rate of unemployment and is appropriately signed. This implies that, any $1 \%$ increase in real output per head leads to a reduction in unemployment by $13.84 \%$ supporting the results of empirical studies conducted in Pakistan by Hussain, Siddiqi and Iqbal (2010); Khan, Khattak and Hussain (2012); and Onwachukwu, 2015 in Nigeria. The coefficient of Agricultural sector proxied by real agricultural output (LNAGRIC) is -0.264209. Thus, a negative and statistically relevant relationship exists between Unemployment rate and the agricultural sector in enhancing inclusive growth in Nigeria. If real agricultural output increases by $1 \%$, unemployment rate fall by $0.26 \%$ creating a higher prospect for investment in the sector and consequently resulting to an improvement in the development of the economy which is in line with the findings of Olajide, Akinlabi and Tijani (2012) in Nigeria.

On the other hand, the manufacturing sector as well as trade openness is positively signed and statistically insignificant in its link with unemployment rate in Nigeria which failed to conform to a priori reasoning. By implication, any $1 \%$ increase or decrease in real manufacturing output and export proceeds results to a $4.18 \%$ and $1.41 \%$ rise or fall in unemployment rate. Therefore, manufacturing sector and openness have no impact in curbing employment rate in Nigeria due to the deplorable and ineffective state of its performance over time. Finally, industrial sector proxied by real industrial output is positive and statistically significant in determining the rate of unemployment in Nigeria. The long run tie suggests that, any 1 percent expansion or contraction in industrial output will lead to 8.95 percent contraction or expansion in the rate of unemployment in Nigeria invariably driving the economy towards achieving inclusive growth.This result contradicted the study of Njoku and Ihugba (2014) in Nigeria who claimed that, the performance of industrialization is below expectations. Thus, inclusive growth is feasible when the unemployment rate can be reduced to the barest minimum to absorb the teeming unemployed Nigerians in the agricultural and industrial sectors. 


\subsection{The Short-Run Dynamic Relationships}

Since all the variables are cointegrated after the first difference, the need to restore any likely deviation capable of influencing the model in its drive to equilibrium become expedient. In applying the short-run dynamics of the ARDL error correction model, four (4) was chosen by Akaike Information criterion as the optimal lag length to be used in estimating the bounds tests. To be consistent with Pesaran and Shin (1999), the SBC is largely preferred to other criteria because it tends to define more parsimonious specifications, although, Lutkepohl (2005) argued that AIC is better for small sample size which necessitates its use in this study. However, the estimated results from equation 3.9 are depicted below in Table 4.

Table 4. Dynamics of short run error correction

\begin{tabular}{|c|c|c|c|}
\hline Variable & Coefficient & t-Statistic & Probability \\
\hline $\mathrm{D}(\operatorname{UEMR}(-1))$ & 0.423968 & 2.438967 & 0.0247 \\
\hline $\mathrm{D}(\operatorname{UEM}(-2))$ & 0.238684 & 1.253296 & 0.2253 \\
\hline D(LNGPC) & -84.626674 & -2.747151 & 0.0128 \\
\hline D(LNGPC(-1)) & 39.434776 & 3.175522 & 0.0050 \\
\hline D(LNGPC(-2)) & 4.177844 & 0.483232 & 0.6345 \\
\hline D(LNGPC(-3)) & -17.579982 & -2.080981 & 0.0512 \\
\hline D(LNAGRIC) & 34.380314 & 2.811045 & 0.0112 \\
\hline D(LNAGRIC(-1)) & -20.166623 & -2.639681 & 0.0162 \\
\hline D(LNMANUF) & 26.178747 & 3.1977081 & 0.0047 \\
\hline D(LNINDUS) & 22.818306 & 1.807984 & 0.0865 \\
\hline D(LNINDUS(-1)) & -20.702319 & -2.701800 & 0.0141 \\
\hline D(LNINDUS(-2)) & -0.385775 & -0.050416 & 0.9603 \\
\hline D(LNINDUS(-3)) & 19.942864 & 2.484363 & 0.0225 \\
\hline $\mathrm{D}(\mathrm{OPNX})$ & -4.835661 & -0.747182 & 0.4641 \\
\hline D(@TREND) & 1.255404 & 4.243176 & 0.0004 \\
\hline ECM(-1) & -0.804151 & -4.417460 & 0.0003 \\
\hline \multicolumn{4}{|c|}{$\begin{array}{l}\text { ECM=UEMR-(-62.4560*LNGPC+32.1928*LNAGRIC+9.4937*LNMANUF+11.1296*LNINDUS-37.3457*O } \\
\text { PNX-147.6531+1.5612*@TREND) }\end{array}$} \\
\hline $\mathrm{R}^{2}=0.600590$ & \multicolumn{3}{|c|}{ Durbin-Watson Stat $=0.801334$} \\
\hline ADJUSTED R ${ }^{2}=0.549384$ & \multicolumn{3}{|c|}{ F-Statistic $=11.72882$} \\
\hline Prob (F-statistic) $=0.000001$ & & & \\
\hline
\end{tabular}

Source: Author's Computations; ARDL $(3,4,2,1,4,1)$ as selected by AIC with UEMR as the dependent variable

Table 4 describes the dynamics of the short-run adjustment process evaluated by the error correction model which expressed how fast variables respond to shock in its return to equilibrium. The coefficient estimate for the $\mathrm{ECM}_{\mathrm{t}-1}$ $(-0.804151)$ term is negative and statistically significant (-4.417460) suggesting that, any alteration in an attempt to curb unemployment in Nigeria will be restored at a speed of $80 \%$ in the next year by agricultural and industrial sectors. In other words, the negative and statistically significant ECM term is an indication that, the feedback mechanism is effective in restoring any external imbalances. The statistical significance of the error correction model reassures the presence of long-run relationship streaming from real gross domestic product per capita, agricultural sector, manufacturing sector, industrial sector and trade openness to unemployment rate in Nigeria.

The coefficient of determination $\mathrm{R}^{2}(0.600590)$ explains the joint influence of the explanatory variables in taking notes of the flux in the dependent variable (unemployment rate). Therefore, changes in the unemployment rate are explained by 60 percent variation in the explanatory variables while 40 percent come from other variables outside the 
model. The F-statistic (11.72882) is greater than 5\% and whose probability $(0.000001)$ is significant and robust in explaining the reliability of the model. Hence, the F-statistic explained the joint statistical significance of the explanatory variables at $5 \%$ level of significance. More remarkably, the Durbin-Watson statistic though weak at $(0.801334)$ but greater than the coefficient of determination $R^{2}(0.600590)$ indicating that, there is no serial correlation in the model utilized.

\subsection{Post Diagnostic Test}

One major hurdle with time series regression is the fact that the parameter estimates change over time. In an event of volatile parameters, model misspecification become inevitable if left unidentified giving rise to a biased estimate (Narayan \&Smiyth, 2005). To justifythis, the relevance of the dynamic results was examined to ensure that the models employeddid not suffer from the problems of non-normality of error term, auto-correlated residuals and heteroscedasticity. The results are presented in Table 5.

Table 5. Post diagnostic test

\begin{tabular}{llll}
\hline LM & test statistic & Chi-Statistic $\mathbf{X}^{\mathbf{2}}$ & Probability \\
\hline 1. & Serial Correlation(*) & 2.343091 & 0.5258 \\
\hline 2. & Heteroskedasticity(**) & 29.32849 & 0.7063 \\
\hline 3. & Functional form(***) & 0.014047 & 0.9057 \\
\hline 4. & Normality test $(* * *)$ & J-B $(0.795295)$ & 0.671899 \\
\hline
\end{tabular}

Note: where $(*),(* *)(* * *)$ and $(* * * *)$ describes Breusch-Godfrey LM test for serial correlation, Breusch-Pagan Godfrey heteroscedasticity test, Ramsey RESET test for omitted variables and, Jarque-Bera Normality test

The robustness tests of the model revealed that Breusch-Godfrey serial correlation LM test, heteroscedasticity test, Jarque-Bera normality test and Ramsey RESET specification test had correct functional form and the model's residuals were serially unrelated, normally distributed and homoskedastic. Also, Parameter stability verified via CUSUM and CUSUMSQ statistic indicates absence of instability of the coefficients since the plots of the two statistics were restricted within the $5 \%$ critical bounds related to the parameter stability. The normality and stability test are represented in appendix vi ( $\mathrm{d}$ and e) respectively.

\section{Conclusion}

This study employed autoregressive distributed lag model to ascertain if curbing unemployment via job creation can serve as panacea to attaining inclusive growth in Nigeria over the period 1970 to 2014. Estimated results from the research uncovered that improvement in the agricultural, manufacturing and industrial sectors will considerably reduce the problems of unemployment and poverty in Nigeria. Even though the manufacturing sector shows no contribution to reducing unemployment, this could be as a result of the use of modern machineries in most manufacturing companies that rendered the use of labour redundant in most cases. Nevertheless, if the teeming unemployed populace are adequately trained in the right direction, the manufacturing sector can still absorbed them. The findings also shows that, curbing unemployment precipitate inclusive growth in the long run because the impact of these sectors in reducing unemployment might not be felt instantaneously in the short run. Thus, it can be submitted by this study that, Government should give utmost priority to the key indicators of inclusive growth that are needful at a given period of time in order to ascertain the right combination of the sectors in which these scarce resources should be directed to with the intention of enhancing inclusive growth. Also, a safe and conducive environment should be provided by the government for these sectors to thrive in order to attract not only residence of the country but foreign investors too. These sectors will end up recruiting the unemployed massively if they have a good environment to operate. Consequently, in order to improve the agricultural sector, special incentives should be given to farmers by the government in form of adequate funding as well as provision of infrastructural facilities such as good roads, pipe borne water, health care and electricity.

\section{References}

Acemoglu, D. (1997). Technology, unemployment and efficiency. European Economic Review, 41(5), 525-533. https://doi.org/10.1016/S0014-2921(97)00019-6 
Adawo, M. A., Essien, E. B., \& Ekpo, N. U. (2012). Is Nigeria's unemployment problem unsolvable?. Current Research Journal of Social Sciences, 4(6), 369-395.

Ali, I., \& Zhuang, J. (2007). Inclusive growth toward a prosperous Asia: Policy implications. African Development Bank Economic and Research Department Working Paper Series.

Anyanwu, J. C. (1997). Nigerian public finance (1st ed.). Onisha: Joane Publisherrs.

Bello, T. (2003). Attacking unemployment hurdles in the fragile economies of the Sub-Saharan Africa: the experience of Nigeria. A paper presented at the-Economics for the Future-Conference; on the Occasion of the Celebration of 100 years of Cambridge Economics; Cambridge, United Kingdom September.

Berg, A., \& Ostry, J. D. (2011). Inequality and unsustainable growth: Two sides of the same coin?. IMF Staff Discussion Note 11/08, Washington: International Monetary Fund. https://doi.org/10.5089/9781463926564.006

Busari, D. T. (2005). Foreign capital, globalization and the challenges of industrialization in Nigeria. In The challenges of industrialization: A pathway to Nigeria becoming a highly industrialized country in the year 2015 (pp. 521-551). Nigerian Economic Society, Ibadan.

Central Bank of Nigeria. (2014). Annual reports and statement of accounts for the year ended $31^{\text {st }}$ December 2015 , Abuja, Central Bank of Nigeria.

Emeh, I. E. J. (2012). Tackling youth unemployment in Nigeria; the Lagos State development and empowerment programmes initiatives. Afro-Asian Journal of Social Sciences, 3(3.4), 1-30.

Engel, R., \& Granger, C. J. (1987). Cointegration and error correction. Representation, Estimation and Testing. Econometrica, (55), 251-276. https://doi.org/10.2307/1913236

Haug, A. (2002). Temporal aggregation and power of cointegration tests: a Monte Carlo study. Oxford Bulletin of Economics and Statistics, 64(2002), 399-412. https://doi.org/10.1111/1468-0084.00025

Hussain, T., Siddiqi, M. W., \& Iqbal, A. (2010). A coherent relationship between economic growth and unemployment: An empirical evidence from Pakistan. International Journal of Human and Social Sciences, 5(5), 332-339.

Ianchovichina, E., \& Lundstrom, S. (2008). What are the constraints to inclusive growth in Zambia?. The World Bank.

ILO. (2009). International labour organization. Labour Statistics Year book, Geneva.

Johansen, S., \&Juselius, K. (1990). Maximum likelihood estimation and inference on cointegration with applications to the demand for money. Oxford Bulletin of Economics and Statistics, 52(2), $169-210$. https://doi.org/10.1111/j.1468-0084.1990.mp52002003.x

Khan, A. Q. K., Khattak, N. U. R. K., \& Hussain, A. H. (2012). Inter-dependences and causality in the Macroeconomic Variables: Evidence from Pakistan (1960-2005).

Kraay, A. (2004). When Is Growth Pro-Poor? Cross-Country Evidence. IMF Working Paper, 4(47), Washington, DC. https://doi.org/10.5089/9781451846676.001

Lütkepohl, H. (2005). New introduction to multiple time series analysis. Cambridge University Press, Cambridge. https://doi.org/10.1007/978-3-540-27752-1

McKinley, T. (2010). Inclusive growth criteria and indicators: an inclusive growth index for diagnosis of country progress. Asian Development Bank Working Paper, 14.

Mike, U. (2015). Unemployment in Nigeria and solution.

Narayan, P. K. (2011). The savings and investment nexus for China: Evidence from cointegration test. Applied Economics. Retrieved from www.informaworld.com/smpp/tittle-content=713684000

Narayan, P. K., \& Smyth, R. (2005). Trade liberalization and economic growth in Fiji. An empirical assessment using the ARDL approach. Journal of the Asia Pacific Economy, 10(1), 96-115. https://doi.org/10.1080/1354786042000309099

National Economic Empowerment and Development Strategy (NEEDS). (2004). Federal Government of Nigeria National Planning Commission, Abuja.

Njoku, A., \& Ihugba, O. A. (2011). Unemployment and Nigerian Economic growth. A proceeding of the 2011 international conference on teaching, learning and change, International Association for Teaching and Learning (IATEL) (pp. 1-11). 
Nkwatoh, L. S. (2015). The Nexus between entrepreneurship development and unemployment: implication for economic growth in Nigeria. https://doi.org/10.11114/aef.v2i2.788

Obioma, E. C., \&Ozugahalu, U. M. (2005). Industrialization and Economic Development: A Review of Major Conceptual and Theoritical Issues. In The Challenges of Industrialization: A Pathway to Nigeria becoming a Highly Industrialized Country in the Year 2015 (pp. 63-97). Nigerian Economic Society, Ibandan.

Ogbalubi, L. N., \& Wokocha, C. (2013). Agricultural development and employment generation: the Nigeria Experience. Journal of Agriculture and Veterinary Science, 2(2), 60-69. https://doi.org/10.9790/2380-0226069

Oji-Okoro, I. (2011). Analysis of the contribution of agricultural sector on the Nigerian economic development. World Review of Business Research, 1(1), 191-200.

Okun, A. M. (1962). Potential GNP: Its Measurement and Significance. In Proceedings of the business and economic statistics section of the American statistical association. American Statistical Association, Washington, DC.

Olajide, O. T., Akinlabi, B. H., \& Tijani, A. A. (2012). Agricultural resources and Economic growth in Nigeria. European Scientific Journal, 8(22), 102-115.

Omoruyi, F. E. O., \& Osunde, A. U. (2004). Evaluating the effectiveness of the national youth employment and vocational skill acquisition programme in Mid-West. Nigeria. Retrieved from www.iiz.dvv.defindex

Onwachukwu, C. I. (2015). Does unemployment significantly impact on economic growth in Nigeria?. Global Journal of Human Social Sciences, E-Economics, 15(8), 23-26.

Pesaran, H. M., \& Shin, Y. (1997). Autoregressive Distributed Lag Model Approach to Cointegration Analysis. DAC Working paper series No 9514, Department of Applied Economics, University of Cambridge.

Pesaran, M. H., Shin, Y., \& Smith, R. J. (2001). Bounds testing approaches to the analysis of level relationships. Journal of Applied Econometrics, 16, 289-326. https://doi.org/10.1002/jae.616

Rauniyar, G., \& Kanbur, R. (2009). Inclusive growth and inclusive development: a review and synthesis of Asian development bank literature. African Development Bank Working Paper Series. https://doi.org/10.1080/13547860.2010.517680

Udo, N. E. (2014). Nigerian Industrial policies and industrial sector performance: Analytical exploration. Journal of Economics and Finance, 3(4), 1-11. https://doi.org/10.9790/5933-0340111

Umar, A., Donga, M., \& Salihu, M. (2013). An empirical investigation into the effects of unemployment and inflation on economic growth in Nigeria. Interdisciplinary Journal of Research in Business, 2(12), 1-14.

World Bank. (2015). World development indicators [CD Rom 2015]. World Bank, Washington, DC.

\section{Copyrights}

Copyright for this article is retained by the author(s), with first publication rights granted to the journal.

This is an open-access article distributed under the terms and conditions of the Creative Commons Attribution license (http://creativecommons.org/licenses/by/4.0/). 